\title{
Total Clearance Predicted Normalized by Body Mass Index
}

National Cancer Institute

\section{Source}

National Cancer Institute. Total Clearance Predicted Normalized by Body Mass Index. NCI Thesaurus. Code C92421.

The predicted total body clearance for intravascular administration divided by the body mass index. 